\title{
Hollandaise challenge
}

\author{
Hervé This ${ }^{1,2}$
}

(C) Springer-Verlag Berlin Heidelberg 2016

We would like to invite you to participate in the Analytical Challenge, a series of puzzles to entertain and challenge our readers. This special feature of "Analytical and Bioanalytical Chemistry" has established itself as a truly unique quiz series, with a new scientific puzzle published every other month. Readers can access the complete collection of published problems with their solutions on the ABC homepage at http://www. springer.com/abc. Test your knowledge and tease your wits in diverse areas of analytical and bioanalytical chemistry by viewing this collection.

In the present challenge, Hollandaise is the topic; and please note that there is a prize to be won (a Springer book of your choice up to a value of $€ 100)$. Please read on...

\section{Meet the challenge}

Today, Hollandaise sauce is made from an initial thermal processing of egg yolks whipped with water. After the mixture whitens and thickens, melted butter is dispersed with a whisk and then lemon juice (or sometimes vinegar), salt, and pepper are added. Hollandaise sauce is closely related to Béarnaise sauce, which is derived from the former mainly by the replacement of water with boiled wine or vinegar, and the addition of tarragon.

Hervé This

herve.this@agroparistech.fr

1 Groupe de Gastronomie Moléculaire, Inra-AgroParisTech International Centre for Molecular Gastronomy, 75005 Paris, France

2 UMR GENIAL, AgroParisTech, Inra, Université Paris-Saclay, 91300 Massy, France
Why the name of the sauce - Hollandaise? It is not clear. Some say that the sauce was invented in the Netherlands and then taken to France by the Huguenots, but I have not found trustful sources for this. Others explain that the sauce was invented during the wars of the French king Louis XIV in the Netherlands, but these wars took place during the 1670s, whereas Hollandaise sauce appears in literature as early as in 1651 in Le Cuisinier François written by François Pierre de La Varenne: "with good fresh butter, a little vinegar, salt, and nutmeg, and an egg yolk to bind the sauce" [1]. However, Larousse Gastronomique states that "in former times [before Louis XIV] fish 'à la hollandaise' was served with melted butter," thus implying that at one time egg yolks were not a part of the designation hollandaise [2].

\section{The challenge}

Today, Hollandaise sauce is often used to make Eggs Benedict - the name of which is also controversial [3]. Anyway the modern version of the sauce is interesting for molecular gastronomy because it can fail either when it is heated for too long, or when too much butter is added, both of which can lead to a phase separation. This was aptly summarized by the famous chef MarieAntoine Carême in 1847: "hollandaise sauce is prone to fail into butter when it waits" [4]. But the failure of the sauce is perhaps not an issue because some chefs say that a smooth appearance of Hollandaise can be recovered simply by the addition of cold water.

Is it true? If so, why? 


\section{References}

1. La Varenne PF. Le Cuisinier françois. Lyon: Jacques Canier; 1651.

2. Montagné P. Larousse gastronomique. Paris: Larousse; 1981.

3. Beyer G. Was he the eggman? N Y Times. 2007. April 8.

4. Carême MA. L'Art de la cuisine française au XIXe siècle. Éditions De Kérangué et Pollès: Paris 1981; 1847. 3:51.
We invite our readers to participate in the Analytical Challenge by solving the puzzle above. Please send the correct solution to abc-challenge@springer.com by August 1, 2016. Make sure you enter "Hollandaise challenge" in the subject line of your e-mail. The winner will be notified by e-mail and his/her name will be published on the "Analytical and Bioanalytical Chemistry" homepage at http://www.springer.com/abc and in the journal (volume 408/issue 27) where readers will find the solution and a short explanation.

The next Analytical Challenge will be published in 408/22, September 2016. If you have enjoyed solving this Analytical Challenge, you are invited to try the previous puzzles on the ABC homepage. 